JASEM ISSN 1119-8362

All rights reserved
Full-text Available Online at www.bioline.org.br/ja
J. Appl. Sci. Environ. Mgt. June, 2006

Vol. 10 (2) 95 - 98

\title{
Contamination of Kallar Kahar Lake by Inorganic Elements and Heavy Metals and their Temporal Variations
}

\author{
FURHAN IQBAL ${ }^{1}$, NADEEM RAZA ${ }^{2}$, MUHAMMAD ALI $^{1}$, MOHAMMAD ATHAR $^{3}$ \\ ${ }^{1}$ Institute of Pure and Applied Biology, Bahauddin Zakariya University, Multan, PAKISTAN. \\ ${ }^{2}$ Department of Chemistry, Bahauddin Zakariya University, Multan, PAKISTAN. \\ ${ }^{3}$ California Department of Food and Agriculture, 1220 N Street, Sacramento, CA 95814, USA.
}

\begin{abstract}
The present study was conducted to find out the contamination of Kallar Kahar Lake by inorganic elements and heavy metals and the temporal variation of these chemicals in the lake water. Water samples were collected on monthly basis during December 2001 to November 2002. Concentration of 10 inorganic elements and heavy metals (sodium, potassium, magnesium, iron, nickel, cobalt, copper, cadmium, lead and zinc) was analyzed in the lake water by atomic absorption spectroscopy. Mean monthly concentration of the inorganic elements and heavy metals in the lake water was: nickel $0.117 \mathrm{mg}$. $\mathrm{L}^{-1}$, iron $1.456 \mathrm{mg}$. $\mathrm{L}^{-1}$, cobalt $0.061 \mathrm{mg}$. $\mathrm{L}^{-1}$, copper $0.258 \mathrm{mg} . \mathrm{L}^{-1}$, cadmium $0.024 \mathrm{mg} . \mathrm{L}^{-1}$, lead $0.118 \mathrm{mg}$. $\mathrm{L}^{-1}$ sodium $397.970 \mathrm{mg}$. $\mathrm{L}^{-1}$, magnesium $115.710 \mathrm{mg}$. $\mathrm{L}^{-1}$, potassium $28.290 \mathrm{mg} . \mathrm{L}^{-1}$ and zinc $1.412 \mathrm{mg} . \mathrm{L}^{-1}$. Analysis of variance showed temporal variations $(\mathrm{P}<0.001)$ in concentration of inorganic elements and heavy metals in Kallar Kahar Lake water. The present study indicates that the concentrations of inorganic elements and heavy metals were not within the safe limit at the sampling site throughout the period of study and water of Kallar Kahar Lake is not suitable for drinking, farming and aquaculture. @JASEM
\end{abstract}

Kallar Kahar (Kahar means lake) is situated 135 km from Rawalpindi, Pakistan on the motorway in the north side of the salt range. Kallar Kahar is a famous wet land area and is a pleasant shady place for picnics. The lake is salty and shallow and is favorite site for migratory birds during winter season. Rain and mountain brooks are the major water sources of the lake. Human activities have increased the concentration of metals in many of the natural water systems which have raised concerns regarding metal bioaccumulation and human health hazards (Pan and Brugam, 1997). The concentrations at which metals are considered important vary as some are essential at low concentration and toxic at higher levels. With increasing public concern regarding environmental contamination, there is a growing need to monitor, manage and remediate ecological damage (Jarup, 2003, Silva et al. 2005). The concentration of metals in surface water depends on several factors like soil dust, local point sources, natural presence in bedrock and soils, and airborne contribution from long range transport (Frank and Cross, 1974; Pan and Brugam, 1997). In addition, conditions in the catchment and lake are important for the mobility and availability of metals in the water. Rivers and lakes are exposed to atmospheric deposition of anthropogenically derived trace elements. This can create harmful effects on environmental condition and human health due to their toxicity and bioaccumulation in various environmental compartments (Boyed and Tucker, 1998; Jarup, 2003, Silva et al. 2005).

Studies to evaluate the contamination by inorganic elements and heavy metals in fresh water bodies are getting worldwide attention during recent years. Elemental concentration in various water reservoirs has been studied in Horseshoe Lake, Illinois (Brugam et al. 2003), Crystal Lake, Illinois (Pan and Brugam, 1997), Lake Balaton (Farkas et al. 2003; Hlavay and Polyak 2002; Nguyen et al. 2005; Weisz et al. 2000), Pearl River Estuary (Liu et al. 2003), Lake Nakuru, Kenya (Mavura and Wangila, 2003), River-WetlandLake system of Balton Region, Hungary (ElbazPoulichet et al. 1997) and lake and fish farm Ibadan, Nigeria (Olaif et al. 2003). Lake Victoria in Kenya has been most frequently studied for pollutants and contaminants (Kondoro, 1998; Onyari and Wandiga, 1989; Tole and Shitsama, 2000; Wandiga and Onyari, 1987). There are not much environmental studies on various lakes, ponds and fresh water bodies in Pakistan. However, there are some sporadic reports on elemental concentration in various fresh water bodies of Pakistan (Chaudhary et al. 1999, Iqbal et al. 2004, Salam et al. 2000). Kallar Kahar Lake is contaminated by sewage water and information regarding the concentration of inorganic elements of lake water is lacking. The present study was conducted to find out the contamination of Kallar Kahar Lake by inorganic elements and heavy metals and the temporal variation of these elements in the lake water.

\section{MATERIALS AND METHODS}

The study on the concentration of inorganic elements and heavy metals in the water of Kallar Kahar Lake, Chakwal, Pakistan was conducted during December 2001 through November 2002. Kallar Kahar Lake was first surveyed to determine the best locations to take the water samples. Samples were collected from the subsurface of lake in $1.5 \mathrm{~L}$ plastic bottles on monthly basis from the same spots on eastern bank of the lake. Water samples were kept refrigerated until 
they were analyzed in the lab. following standard methods. Atomic absorption spectroscopic measurements and computations were made following Ansari and Iqbal (1993), Chaudhary et al. (1999) and Salam et al. (2000). Data were subjected to analysis of variance to compare monthly variations of concentration of inorganic elements and heavy metals.

\section{RESULTS}

The results about concentration of inorganic elements and heavy metals are provided in Table 1 . Analysis of variance showed temporal variations $(\mathrm{P}<0.001)$ in concentration of inorganic elements and heavy metals in Kallar Kahar Lake water (Table 2). Mean monthly concentration of nickel was $0.117 \mathrm{mg}$. $\mathrm{L}^{-1}$ during the study period. The maximum concentration of nickel was observed in January $\left(0.25 \mathrm{mg} . \mathrm{L}^{-1}\right)$ and minimum in December $\left(0.04 \mathrm{mg}\right.$. $\left.\mathrm{L}^{-1}\right)$ which was significantly different $(\mathrm{P}<0.001)$ from each other. The iron concentration was the highest in April (5.46 mg. $\mathrm{L}^{-1}$ ) and the lowest in August $\left(0.20 \mathrm{mg}\right.$. $\mathrm{L}^{-1}$ ) while the mean monthly concentration was $1.456 \mathrm{mg}^{-1} \mathrm{~L}^{-1}$. Concentration of cobalt ranged between $0.01 \mathrm{mg}^{-1}$ in December to $0.16 \mathrm{mg}^{-1} \mathrm{~L}^{-1}$ in June. Mean monthly concentration of cobalt was $0.061 \mathrm{mg}$. $\mathrm{L}^{-1}$. Concentration of cobalt was below the detection level during January to March, and July and August. The maximum concentration of copper was observed in March (1.20 mg. $\left.\mathrm{L}^{-1}\right)$ and minimum in September and October (0.01 mg. $\left.\mathrm{L}^{-1}\right)$. Mean monthly concentration of copper was 0.258 during the study period. Cadmium was not detected in March and April but it showed significant $(\mathrm{P}<0.001)$ variation during other months. The maximum cadmium concentration was observed in July (0.05 mg. $\mathrm{L}^{-1}$ ) and minimum in
December (0.01 mg. $\left.\mathrm{L}^{-1}\right)$. Mean monthly concentration of cadmium was $0.024 \mathrm{mg}$. $\mathrm{L}^{-1}$ during the study period. Lead was not detected in January, February and July to October but could be detected during the later months. The maximum lead concentration was observed in June $\left(0.30 \mathrm{mg} . \mathrm{L}^{-1}\right)$ and minimum in November $\left(0.01 \mathrm{mg}\right.$. $\left.\mathrm{L}^{-1}\right)$. Mean monthly concentration of lead was $0.118 \mathrm{mg}$. $\mathrm{L}^{-1}$ during the study period. The sodium concentration ranged between $250.10 \mathrm{mg}$. $\mathrm{L}^{-1}$ in January to 650.14 mg. $\mathrm{L}^{-1}$ in October. Mean monthly sodium concentration was $397.970 \mathrm{mg}$. $\mathrm{L}^{-1}$. The maximum concentration of magnesium was observed in November (249.120 mg. $\mathrm{L}^{-1}$ ) and minimum in January (51.48 mg. $\left.\mathrm{L}^{-1}\right)$. Mean monthly concentration of magnesium was $115.710 \mathrm{mg}$. $\mathrm{L}^{-1}$ during the study period. The concentration of copper ranged from $0.01 \mathrm{mg}$. $\mathrm{L}^{-1}$ in September and October to $1.20 \mathrm{mg}$. $\mathrm{L}^{-1}$ in March. Mean monthly concentration of copper was $0.258 \mathrm{mg}^{-1} \mathrm{~L}^{-1}$ during the study period. The potassium concentration ranged between $20.27 \mathrm{mg}$. $\mathrm{L}^{-1}$ in October to $33.880 \mathrm{mg}$. $\mathrm{L}^{-1}$ in May. Mean concentration of potassium was $28.290 \mathrm{mg}$. $\mathrm{L}^{-1}$. Cobalt was not detected from January to March and July to August. Mean monthly concentration of cobalt was $0.061 \mathrm{mg}$. $\mathrm{L}^{-1}$. The concentration of cobalt ranged from $0.01 \mathrm{mg}$. $\mathrm{L}^{-1}$ in December to $0.16 \mathrm{mg}$. $\mathrm{L}^{-1}$ in June. Zinc was not detected in January, April to June and from August to November but it showed variation during the later months. The maximum zinc concentration was observed in March (2.82 mg. $\mathrm{L}^{-1}$ ) and minimum in July $\left(0.44 \mathrm{mg}\right.$. $\left.\mathrm{L}^{-1}\right)$. Mean monthly zinc concentration was $1.412 \mathrm{mg}$. $\mathrm{L}^{-1}$ during the study period.

Table 1. Temporal variations in concentration $\left(\mathrm{mg}^{-\mathrm{L}^{-1}}\right.$ ) of inorganic elements and heavy metals in Kallar Kahar Lake water.

\begin{tabular}{lllllllllll}
\hline Months & $\mathrm{Ni}$ & $\mathrm{Fe}$ & $\mathrm{Co}$ & $\mathrm{Cu}$ & $\mathrm{Cd}$ & $\mathrm{Pb}$ & $\mathrm{Na}$ & $\mathrm{Mg}$ & $\mathrm{K}$ & $\mathrm{Zn}$ \\
\hline December 2001 & 0.04 & 2.64 & 0.01 & 0.15 & 0.01 & 0.28 & 304.23 & 60.34 & 29.48 & 1.94 \\
& & & & & & & & & & \\
January 2002 & 0.25 & 2.36 & - & 0.13 & 0.02 & - & 250.10 & 51.48 & 28 & - \\
& & & & & & & & & & \\
February 2002 & 0.13 & 0.87 & - & 1.17 & 0.03 & - & 292.38 & 91.3 & 28.98 & 0.45 \\
March 2002 & 0.08 & 1.23 & - & 1.20 & - & 0.17 & 510.91 & 128.10 & 31.31 & 2.82 \\
April 2002 & 0.06 & 5.46 & 0.05 & 0.10 & - & 0.09 & - & - & - & - \\
May 2002 & 0.08 & 0.48 & 0.06 & 0.10 & 0.02 & 0.11 & 281.97 & 115.25 & 33.88 & - \\
June 2002 & 0.12 & 0.23 & 0.16 & 0.06 & 0.03 & 0.30 & 371.51 & 86.02 & 30.50 & - \\
July 2002 & 0.21 & 0.34 & - & 0.10 & 0.05 & - & - & - & - & 0.44 \\
August 2002 & 0.10 & 0.20 & - & 0.04 & 0.02 & - & 317.51 & 70.11 & 27.26 & - \\
September 2002 & 0.13 & 0.72 & 0.03 & 0.01 & 0.01 & - & 440.2 & 94.01 & 20.88 & - \\
October 2002 & 0.11 & 0.42 & 0.06 & 0.01 & 0.03 & - & 650.14 & 201.3 & 20.27 & - \\
November 2002 & 0.10 & 2.52 & 0.06 & 0.03 & 0.03 & 0.01 & 550.79 & 247.12 & 31.33 & - \\
Mean & 0.117 & 1.456 & 0.06 & 0.258 & 0.02 & 0.11 & 397.97 & 115.97 & 28.29 & 1.41 \\
& \pm 0.05 & \pm 1.557 & 1 & \pm 0.435 & 4 & 8 & 0 & \pm 63.24 & \pm 4.42 & 2 \\
& & & \pm 0.0 & & \pm 0.0 & \pm 0.1 & \pm 134.3 & & & \pm 1.1 \\
\hline
\end{tabular}




\section{DISCUSSION}

The physical, chemical and biological processes occurring permanently in an aquatic environment should be considered to explain the inorganic elements and heavy metals concentrations (Nguyen et al. 2005). External processes like discharging of pollutants and anthropogenic activities also affect the concentration and behavior of inorganic elements and heavy metals concentrations (Baeyens et al. 1998). Dissolved metal ions create turbidity and discoloration of lake water. They can precipitate and form bottom sludge. Limits on individual metals are usually based on toxicity levels. Various metals including those which are essential micronutrients are toxic to organisms at their higher concentrations. Normally the free form of the element is potentially toxic to aquatic biota. Complexation with organic ligands significantly reduces their concentration and the adverse effects. Other factors such as $\mathrm{pH}$ and hardness also affect the concentration of free metal ions and thus regulate toxicity. However, several regulatory agencies have specified limits on total metals to provide a sufficient safeguard against possible synergistic effects.

The concentration of sodium increased in winter season when the water level in the lake was low and decreases in summer season when water flow in lake was high. The concentration of sodium ions becomes remarkably high in saline and brackish water. The higher concentration of sodium limits the biological diversity due to osmotic stress. High sodium contents in the form of chloride and sulfates make the water salty and unfit for human consumption. High sodium content in irrigation water brings about puddling of soil. As a result the water infiltration in the soils is reduced and the soil becomes hard making the germination of seed difficult (Trivedi and Gurdeep, 1992)

Potassium plays the same role in water as sodium. It occurs in small amounts but is regarded as an important macronutrient in the metabolism of freshwater environments (Trivedi and Gurdeep, 1992). Magnesium occurs in all natural waters. It is an essential constituent of chlorophyll and no ecosystem could work without it. High magnesium concentration in water reduces its quality for domestic use, while a concentration above $500 \mathrm{mg}$. $\mathrm{L}^{-}$ ${ }^{1}$ gives an unpleasant taste and make it unfit for drinking purposes (Trivedi and Gurdeep, 1992). The magnesium concentration $\left(115.71 \mathrm{mg} . \mathrm{L}^{-1}\right)$ in Kallar Kahar Lake water is higher than the standard magnesium concentration (30 mg. $\left.\mathrm{L}^{-1}\right)$ in water.
Table 2. ANOVA table showing temporal variations in concentration of inorganic elements and heavy metals in Kallar Kahar Lake water.

\begin{tabular}{llll}
\hline Metals & df & MS & Significance \\
\hline Nickel & 11,24 & 0.026 & ${ }^{* * *}$ \\
Iron & 11,24 & 7.270 & ${ }^{* * *}$ \\
Cobalt & 11,24 & 0.006 & $* *$ \\
Copper & 11,24 & 0.568 & ${ }^{* * *}$ \\
Cadmium & 11,24 & 0.000061 & ${ }^{* * *}$ \\
Lead & 11,24 & 0.030 & ${ }^{* * *}$ \\
Sodium & 11,24 & 116287 & ${ }^{* * *}$ \\
Magnesium & 11,24 & 15904.20 & ${ }^{* * *}$ \\
Potassium & 11,24 & 411.86 & ${ }^{* * *}$ \\
Zinc & 11,24 & 2.57 & ${ }^{* * *}$ \\
\hline
\end{tabular}

Iron is quantitatively regarded the most important trace metal for autotrophs due to its indispensability for many enzymes and redox processes. Iron concentration up to $0.1 \mathrm{mg}$. $\mathrm{L}^{-1}$ is acceptable while 1 mg. $\mathrm{L}^{-1}$ or more iron in fresh water could be harmful for life (Trivedi and Gurdeep,1992). Mean monthly concentration of iron in present study was $1.456 \mathrm{mg}$. $\mathrm{L}^{-1}$ which does not falls in safe limits recommended by Trivedi and Gurdeep (1992).

Copper, chromium, cadmium and zinc are among the heavy metals. The source of these heavy metals in fresh water bodies is mainly through industrial effluent. In freshwater bodies, the acceptable level of copper and chromium is $0.05 \mathrm{mg} . \mathrm{L}^{-1}$, cadmium is $0.01 \mathrm{mg}$. $\mathrm{L}^{-1}$ and zinc is $5 \mathrm{mg}$. $\mathrm{L}^{-1}$ (Trivedi and Gurdeep, 1992). The concentration of all these metals was higher than the normal standards which could be life threatening. The present study indicates that the concentrations of inorganic elements and heavy metals were not within the safe limit at the sampling site throughout the study period and water of Kallar Kahar Lake is not suitable for drinking, farming and aquaculture.

\section{REFERENCE}

Ansari, TM; Iqbal, M (1993). CPFAAS- A computer programme for comprehensive treatment of data in Flame Atomic Absorption Spectrometry. J. Anal. Environ. Chem. 2: 84-89.

Baeyens, W; Parmentier, K; Goeyens, L; Ducastel, G; De Gieter, M; Leermakers, M (1998). Biogeochemical behaviour of $\mathrm{Cd}, \mathrm{Cu}, \mathrm{Pb}$ and $\mathrm{Zn}$ in Scheldt estuary: results of the 1995 surveys. Hydrobiologia 366:45-62.

Brugam, R; Bala, I; Martin, J; Vermillion, B; Retzlaff, W (2003). The sedimentary record of environmental contamination in Horseshoe Lake, 
Madison County, Illinois. Trans. Illinois State Acad. Sci. 96: 205-217.

Boyd, CE; Tucker, CS (1998). Pond aquaculture water quality management. Kluwer Academic Publishers, London.

Chaudhary, A; Salam, A; Ansari, TM; Nadeem, S (1999). Studies on the effect of seasonal variations on physical and chemical characteristics of Indus river water. J. Pure Appl. Sci. 17: 26-33.

Elbaz-Poulichet, F; Nagy, F; Cserny, T: Pomogyi, P; (1997). Biogeochemistry of trace elements (Mn, $\mathrm{Sr}, \mathrm{Rb}, \mathrm{Ba}, \mathrm{Cu}, \mathrm{Zn}, \mathrm{Pb}$, and $\mathrm{Cd}$ ) in a RiverWetland-Lake system (Balton Region, Hungary). Aquatic Geochemistry 2: 379-402.

Farkas, A; Salanki, J; Varanka, I (2003). Crustaceans as biological indicators of heavy metal pollution in lake Balaton (Hungary). Hydrobiologia 4: 506-509.

Frank, L; Cross, PE (1974). Management primer on water pollution control. Technomic Publishing Company, Inc., West Port. pp: 23-27.

Hlavay, J; Polyak, K (2002). Investigation on the pollution sources of bottom sediments in Lake Balaton. Microchem. J. 73: 65-78.

Iqbal, F; Ali, M; Salam, A; Kokhar, Y (2004). Studies on relationship between season and inorganic elements of river Soan at Dhoak Pathan Bridge (Chakwal), Pakistan. Pak. J. Biol. Sci. : 7 93-95.

Jarup, L (2003). Hazards of heavy metal contamination. Braz. Med. Bull. 68:167-182.

Kondoro, JWA (1998). Heavy metal pollution in Lake Victoria. Tanzania J. Sci. 24: 9-21.

Liu, WX; Li, XD; Shen, ZG; Wang, DC; Wai, OWH; Li, YS (2003). Multivariate statistical study of heavy metal enrichment in sediments of the Pearl River Estuary. Environ. Pollut. 121:377-388.

Mavura, WJ; Wangila, PT (2003). The pollution status of Lake Nakuru, Kenya: heavy metals and pesticides. Afr. J. Aquatic Sci. 114:13-18.
Nguyen, HL; Leermakers, M; Elskens, M; Ridder, FD; Doan, TH; Baeyens, W (2005). Correlations, partitioning and bioaccumulation of heavy metals between different compartments of Lake Balton. Sci. Total Environ. 341:211-226.

Olaifa, FE; Olaifa, AK; Adelaja, AA; Owolabi, AG (2003). Heavy metal contamination of Clarias gariepinus from a lake and fish farm in Ibadan, Nigeria. Afr. J. Biomed. Res. 7:145-148.

Onyari, JM; Wandiga, SO (1989). Distribution of Cr, $\mathrm{Pb}, \mathrm{Cd}, \mathrm{Zn}, \mathrm{Fe}$ and $\mathrm{Mn}$ in Lake Victoria sediments. Bull. Environ. Contamin. Toxicol. 42 :807-812.

Pan, Y; Brugam, RB (1997). Human disturbance and tropic status changes in Crystal Lake, McHenry County, Illinois, USA. J. Paleolimnology 17:369-376.

Salam, A; Ansari, TM; Tariq, N; Akhtar, QA (2000). Effect of body size on metal concentration in farmed Cirrhinus mirgala. Asian Fish. Sci. 15: 329-334.

Silva, ALO: Barrocas, PRG; Jacob, SC; Moreira, JC (2005). Dietary intake and health effects of selected toxic elements. Braz. J. Plant Physiol. 17:79-93.

Tole, MP; Shitsama, JM (2000). Concentrations of heavy metals in water, fish, and sediments of the Winam gulf, Lake Victoria, Kenya. Moi University, Lake Victoria 2000 Conference, Jinja, Uganda.

Trivedi, PR; Gurdeep, R (1992). Environmental water and soil analysis. Akashdeep Publish. House, Delhi, India. pp. 141-152.

Wandiga, SO; Onyari, JM (1987). The concentration of heavy metals: $\mathrm{Mn}, \mathrm{Fe}, \mathrm{Cu}, \mathrm{Zn}, \mathrm{Cd}$ and $\mathrm{Pb}$ in sediments and fish from the Winam Gulf of Lake Victoria and fish bought in Mombasa town markets. J. Sci. 8: 5-18.

Weisz, M; Polyak, K; Hlavay, J (2000). Fractionation of elements in sediment samples collected in rivers and harbors at Lake Balaton and its catchment area. Microchem. J. 67: 207-217. 